Andrea Romero* and Robert M. Timm

\title{
Reproductive strategies and natural history of the arboreal Neotropical vesper mouse, Nyctomys sumichrasti
}

\begin{abstract}
The vesper mouse, Nyctomys sumichrasti (Rodentia: Cricetidae), a poorly known, arboreal, nocturnal, rodent found in Central America, has been considered rare, and limited information is available about its biology, especially reproduction. We obtained vesper mice from several sites in Costa Rica and prepared them as scientific specimens with standard external measurements and reproductive data recorded. We expanded our dataset by including specimens from museum collections. Vesper mice have 1:1 sex ratios throughout their range. They reproduce year-round and litters may occur in rapid succession. Testis size is positively correlated with body mass; however, we could not determine the onset of sperm production. The onset of reproduction for females, based on mass, is variable but most females are parous by $60 \mathrm{~g}$. Litter size is small with a mode of two, and embryos are not evenly distributed across the uterine horns. Vesper mice exhibit striking morphological differences in terms of tooth-wear and pelage patterns across their range. Much work is needed to fully appreciate N. sumichrasti, its role in tropical habitats, and its reproductive biology.
\end{abstract}

Keywords: Central America; embryo balance; litter size; seasonality; sex ratios.

*Corresponding author: Andrea Romero, Department of Ecology and Evolutionary Biology and KU Natural History Museum, 1345 Jayhawk Boulevard, Lawrence, KS 66045, USA, e-mail: romeroa@gmail.com Robert M. Timm: Department of Ecology and Evolutionary Biology and KU Natural History Museum, 1345 Jayhawk Boulevard, Lawrence, KS 66045 USA

\section{Introduction}

The vesper mouse, Nyctomys sumichrasti (Saussure, 1860), is a poorly known, medium-sized cricetid rodent found from Jalisco and Veracruz, Mexico, to central Panama, excluding the Yucatan Peninsula (Hunt et al. 2004, Genoways et al. 2005). Vesper mice are distinctive with an orange to tawny-brown dorsum, white underside, long whiskers, and a long, tufted tail, although there is morphological variation along its range. Vesper mice live in many habitats, including evergreen, semideciduous, old secondary growth, and dry tropical forests (Fleming 1970, Reid 2009), and can be found from lowlands to elevations of 1500-1800 m (Timm et al. 1989, Timm and LaVal 2000). Historically, vesper mice have been treated as belonging to a single species, $N$. sumichrasti; however, recent studies suggest that more than one biological species may be involved (Corley et al. 2011, Timm and Genoways in prep.). Because vesper mice, along with the closely related Yucatan vesper mouse, Otonyctomys hatti Anthony, 1932, belong to a clade of closely related arboreal taxa, we herein will use the common name vesper mouse in discussing the members of this clade that are currently considered the widespread species $N$. sumichrasti.

Vesper mice are nocturnal, arboreal, and move along areas with dense trees and vegetation (Fleming 1970, Schnell et al. 2010). They feed on fruits, flowers, seeds, leaves, and insects (Genoways and Jones 1972, Timm and LaVal 2000, Timm and Vriesendorp 2003, Reid 2009) and use the same habitats in all seasons (DomÍnguez-Castellanos et al. 2007). On average, males travel longer distances than females (Schnell et al. 2010).

Vesper mice generally are considered rare or uncommon (Timm 1994, Timm and Vriesendorp 2003), with densities of 0.87-4.09/ha reported in Colima, Mexico (Schnell et al. 2010); however, they are seemingly locally abundant in the Pacific lowlands of Nicaragua (Genoways and Jones 1972) and the Monteverde region of Costa Rica (Timm and Vriesendorp 2003). Abundance estimates may not be representative of true densities, however, because they are difficult to see and infrequently caught (Fleming 1970, 1973, Ceballos 1990, Dalquest 1996). Vesper mice are hard to capture because traps must be placed above ground level, requiring special equipment, knowledge, and considerable effort; consequently, most aspects of the biology are poorly understood. Knowledge of reproduction is limited to a study of animals raised in captivity, inferences from a study in a Nicaraguan dry forest, incidental captures reported in small mammal surveys, and descriptions of the male reproductive organs (Burt 1960, Arata 1964, 
Hooper and Musser 1964, Birkenholz and Wirtz 1965, Fleming 1970, Genoways and Jones 1972, Sánchez-Hernández et al. 1999, Schnell et al. 2010). Data on reproduction and natural history are especially lacking for populations in the Caribbean lowland wet forests, which differ in patterns of seasonality and rainfall, potentially affecting reproductive strategies.

Basic knowledge on reproduction is critical for understanding how a species functions in its environment and in building accurate demographic and population growth models. Although Nyctomys sumichrasti may be more common than previously thought, its habitat has suffered considerable fragmentation and degradation (SánchezAzofeifa et al. 2001, Peña et al. 2005); thus, studies elucidating its ecology and reproduction are timely. Additionally, this arboreal mouse allows us to test predictions concerning the reproductive strategies of mammals that are highly mobile and agile in tropical environments, characteristics that can affect seasonality of reproduction, litter size, and embryo balance. Most vertebrates in the tropics, including a variety of mammals, show seasonal reproduction (Sasa et al. 2009, Stoner and Timm 2011); however, on the basis of the limited data available for $N$. sumichrasti, we predict year-round reproduction. Because this mouse is arboreal, has relatively large young, and may reproduce year-round, we expect litters to be small and evenly distributed across the uterine horns, given that these are characteristics associated with mammals that rely on speed and agility (Baird and Birney 1985, Birney and Baird 1985). The aim of this article is to (1) determine sex ratios, (2) assess seasonality of reproduction, (3) test for a correlation between testis length and body mass, (4) determine the onset of female reproduction, (5) define litter size, (6) test for embryo balance between uterine horns, and (7) provide new information on the natural history and abundance of this poorly known species.

\section{Materials and methods}

We obtained Nyctomys sumichrasti from several sites in Costa Rica, primarily in the northeastern Caribbean lowland tropical wet forests around Estación Biológica La Selva and Reserva Ecológica Bijagual. The 1600-ha La Selva reserve $\left(10^{\circ} 25^{\prime} 52^{\prime \prime} \mathrm{N}, 84^{\circ} 00^{\prime} 12^{\prime \prime} \mathrm{W}\right)$ is owned and managed by the Organization for Tropical Studies and composed of primary forest, secondary forest, and abandoned pasture and plantations, with elevation ranging from $22 \mathrm{~m}$ to just over $140 \mathrm{~m}$. La Selva receives $\sim 4 \mathrm{~m}$ of rain annually, with a short dry season occurring in February to
April (McDade and Hartshorn 1994). Bijagual is a 290-ha private reserve $\left(10^{\circ} 21^{\prime} 48^{\prime \prime} \mathrm{N}, 84^{\circ} 6^{\prime} 12^{\prime \prime} \mathrm{W}\right)$ comprising 210 ha of selectively logged forest, with the remaining area being secondary growth and abandoned pasture. The mean annual rainfall at Bijagual is $5.5 \mathrm{~m}$ and elevation is $300-400 \mathrm{~m}$ above sea level (http://www.bijagual.org). Both reserves are in Heredia Province and connect to Costa Rica's Parque Nacional Braulio Carrillo.

Our complete dataset consists of specimens we prepared and other museum specimens. For the Caribbean lowland sample, reserve managers and private homeowners captured vesper mice that entered buildings from December 2005 to December 2009 (84 individuals). For each individual, we recorded mass, using Pesola scales, and standard external measurements (total length, length of tail vertebrae, length of hind foot, and height of ear from notch) with a standard metric ruler. For females, we assessed (1) if they were nulliparous (defined as not lactating, no embryos, no enlarged mammary tissue, no open vaginal orifice, no enlarged uterus or placental scars); (2) number of embryos; (3) location of embryos (right or left uterine horn); (4) crown-to-rump length of embryos; and (5) size of mammae (visibly enlarged or not) and the condition of the vaginal opening. The testis length and width were measured for males. All specimens were deposited at the University of Kansas Natural History Museum (KU), Lawrence, or the National Museum of Costa Rica (MNCR, Museo Nacional de Costa Rica), San José. Our complete dataset (597 individuals) includes information on specimens from Belize, Costa Rica, El Salvador, Guatemala, Honduras, Mexico, Nicaragua, and Panama, encompassing the entire range for this species. These were housed in the following institutions: American Museum of Natural History, New York; Carnegie Museum of Natural History (CMNH), Pittsburgh; Field Museum of Natural History (FMNH), Chicago; Institute of Biology, National Autonomous University of Mexico, Mexico City; Los Angeles County Museum, Los Angeles; MNCR, San José; Museum of Vertebrate Zoology, Berkeley; Royal Ontario Museum (ROM), Toronto; KU, Lawrence; and U.S. National Museum (USNM), Washington, DC.

\section{Sex ratios}

We tested for deviations from a 1:1 sex ratio using a $\chi^{2}$-test for (1) all age classes (adults, subadults, and juveniles) pooled for individuals from the Caribbean lowlands of Costa Rica, and (2) all age classes and populations pooled for all countries. We did not test sex ratios by age classes because of difficulties in reliably assigning individuals to 
an age class on the basis of the tooth-wear patterns proposed by Genoways and Jones (1972). Although sampling biases can affect sex ratio analyses of a population, it should be reduced in this study owing to our large dataset from museum specimens collected with a variety of techniques. Herein, we follow the same method in testing for sex ratio deviations as has been done for this species in the past (Genoways and Jones 1972, Schnell et al. 2010), and present the best estimates of sex ratios in this species to date.

\section{Reproduction}

We assessed seasonality of reproduction by tallying currently reproductive females (pregnant, lactating, or enlarged mammary tissue) by month for individuals from the Caribbean lowlands only, and for all possible specimens regardless of locality. A Pearson correlation analysis was performed with testis length and body mass. We scored all females we collected, regardless of locality, as reproductive or non-reproductive - females that were lactating, or had embryos, enlarged mammary tissue, an open vaginal orifice, an enlarged uterus, or placental/uterine scars were considered reproductive. We used a binary logistic regression to predict the probability of female reproductive state based on mass. Model fit was assessed using the Hosmer-Lemeshow test. All females with counts of visible embryos, regardless of locality or size of embryos, were used to determine litter size.

\section{Embryo balance}

We evaluated embryo balance in the uterine horns following the protocol outlined by Baird and Birney (1985). All pregnant females with two or more embryos, regardless of collection locality, were included in this analysis. Baird and Birney (1985) classified the embryo distribution for each female as balanced or unbalanced. To be considered balanced, an even-numbered litter would have to be split evenly between the left and right uterine horns; however, an odd numbered litter is considered balanced if one horn had only one more embryo than the other (e.g., a litter size of three was considered balanced if the left horn had one embryo and the right had two embryos or vice versa).

The probabilities for every possible configuration for all litter sizes were determined using the binomial distribution with the probability of left and right being equal. For example, a litter size of three has two possible configurations, 3:0 or 2:1, with probabilities of 0.25 and 0.75 , respectively. We then calculated a $\chi^{2}$ value for the observed distributions of the embryos (right or left uterine horn) for each litter size. Any litter size with an expected number fewer than five was pooled with an adjacent litter size. The $\chi^{2}$ values for all litter sizes were summed and compared with a $\chi^{2}$ distribution to test for significance. See Baird and Birney (1985) for a more detailed description of the method.

Statistical tests were run in MINITAB 14. This project was undertaken with the approval of the University of Kansas Institutional Animal Care and Use Committee. All animal handling protocols were in accordance with the guidelines of the American Society of Mammalogists (Sikes et al. 2011).

\section{Results}

\section{Sex ratios}

We examined 43 males and 41 females in all age classes from the Caribbean lowlands of Costa Rica. This ratio does not differ significantly from 1:1 $\left(\chi_{1}^{2}=0.048, p=0.827\right)$. Our dataset for all countries consists of 291 males and 306 females, totaling 597 individuals. This male-tofemale ratio of 1:1.05 does not significantly differ from 1:1 $\left(\chi_{1}^{2}=0.377, \mathrm{p}=0.539\right)$.

\section{Reproduction}

Reproduction occurs year-round for both the Caribbean lowland population and for individuals across the geographic range. Parous and nulliparous females were found year-round for the Costa Rican Caribbean lowland population and for the entire dataset (Table 1). Male testis length ranged from 2 to $18 \mathrm{~mm}$ (mean $=9.97 \mathrm{~mm}$, median $=11 \mathrm{~mm}$, $\mathrm{SD}=3.25$ ). Male testis length was positively correlated with body mass $(r=0.659, p<0.001$; Figure 1$)$.

Females with greater mass were more likely to be reproductive. The binary logistic regression was found to be significant, with all coefficients in the model non-zero (log likelihood test, $\mathrm{G}_{1}=43.884, \mathrm{p}<0.001$ ); goodness-offit tests showed no significant deviation from the model (Hosmer-Lemeshow $\chi_{8}^{2}=6.229, \mathrm{p}=0.622$ ). The equation estimating the probability of a female being reproductive is $\mathrm{p}=\mathrm{e}^{\left(-6.81+0.1669^{*} \mathrm{M}\right)} /\left(1+\mathrm{e}^{\left(-6.81+0.166^{*} \mathrm{M}\right)}\right)$, where $\mathrm{p}$ is the probability of being reproductive and $M$ is the mass in grams. The estimated probability of a female being reproductively active begins to increase from 0 at $\sim 20 \mathrm{~g}$. At $\sim 41 \mathrm{~g}$, the probability 
Table 1 Reproductive status of female vesper mice from throughout the range collected by month.

\begin{tabular}{lrrr}
\hline Month & Non-reproductive & \multicolumn{2}{r}{ Reproductive } \\
\cline { 3 - 4 } & & P, L, EMT & EU, US \\
\hline January & $2(2)$ & $3(2)$ & $1(0)$ \\
February & 0 & $3(2)$ & 0 \\
March & $3(0)$ & $5(1)$ & $2(0)$ \\
April & $2(1)$ & $8(2)$ & 0 \\
May & $2(2)$ & $2(1)$ & $1(0)$ \\
June & $3(3)$ & 0 & $1(1)$ \\
July & $4(3)$ & $8(4)$ & $1(1)$ \\
August & $2(1)$ & $3(0)$ & $1(0)$ \\
September & $7(4)$ & $2(1)$ & $2(1)$ \\
October & $4(1)$ & $7(2)$ & $1(0)$ \\
November & 2 & 0 & 0 \\
December & $3(1)$ & $3(1)$ & 0 \\
\hline
\end{tabular}

Reproductive category is broken down into individuals that were currently reproducing (P, pregnant; L, lactating; EMT, enlarged mammary tissue), and those that had signs of past reproduction (EU, enlarged uterus; US, uterine scars). Number reported in parentheses is the number of individuals for each category for the Caribbean lowlands of Costa Rica only.

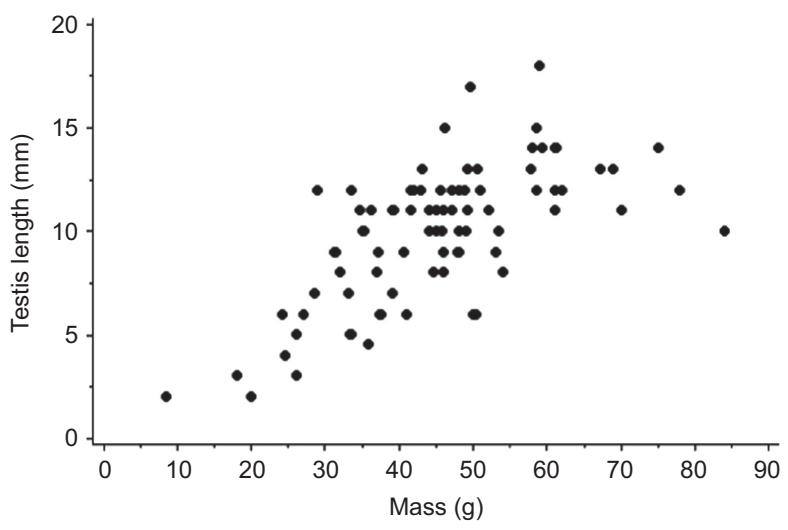

Figure 1 Testis length by mass.

Males from all localities with testis length measurements were included $(\mathrm{n}=87)$.

of a female being reproductive is $50 \%$, which increases to nearly $100 \%$ at $\sim 60 \mathrm{~g}$ (Figure 2). We recognize that pregnant females can confound these results because of embryo weight, and for this reason we reran this analysis excluding pregnant females and found minor differences (e.g., $50 \%$ probability=44 g). Here, we report the analysis including pregnant females because the differences in the logistic regressions are inconsequential, and mass is regularly measured in the field and laboratory without knowledge of pregnancy status, and is therefore a more practical and useful tool.

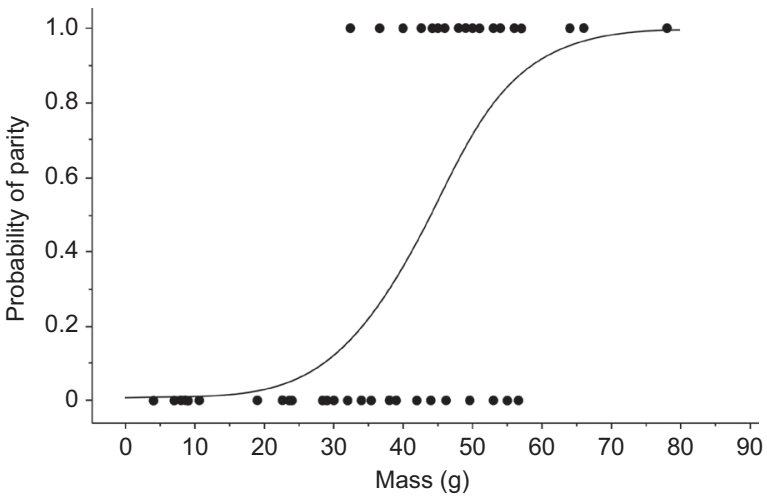

Figure 2 Binary logistic regression for females with reproductive data from all localities $(n=72)$.

Curve represents the probability of a female being reproductively active (parous) by weight. Parous females were individuals that were pregnant, lactating, and/or had enlarged mammary tissue or uterus.

Our lightest reproductive female weighed $32.4 \mathrm{~g}$ and was categorized as having an enlarged uterus with no visible embryos. The heaviest female weighed $87 \mathrm{~g}$ but had no associated reproductive data. Our heaviest reproductive female weighed $80 \mathrm{~g}$ with one embryo measuring $12 \mathrm{~mm}$. The heaviest reproductive female that was not pregnant weighed $78 \mathrm{~g}$. Our heaviest non-reproductive female weighed $56.6 \mathrm{~g}$.

Of 163 females with reproductive data, 24 were pregnant. The number of embryos varied from one to four ( mean $=2.3$, median and mode $=2, \mathrm{SD}=0.806$ ). Crownrump length varied from small embryos $(2 \mathrm{~mm})$ to more developed fetuses $(32 \mathrm{~mm}$ ) (weighted mean $=12.8 \mathrm{~mm}$, $\mathrm{SD}=8.03$ ) (Table 2).

\section{Embryo balance}

Pregnant females with two or more embryos did not exhibit a balanced distribution within the uterine horns $\left(\chi_{1}^{2}=0.9, \mathrm{p}=0.66\right)$ (Table 2).

\section{Discussion}

\section{Sex ratios}

The Caribbean lowland population did not differ from a 1:1 sex ratio for all age classes. Many of our specimens from Costa Rica's Caribbean lowlands were captured when they entered homes, and therefore we mostly sampled 
Table 2 Reproductive data for female vesper mice with embryos, for all countries.

\begin{tabular}{|c|c|c|c|c|}
\hline Date & N & $\mathbf{L}$ & $\mathbf{R}$ & CR \\
\hline 10 Jul 1966 & 1 & 1 & 0 & 6 \\
\hline 9 Feb 2008 & 1 & $\mathrm{~N} / \mathrm{A}$ & $\mathrm{N} / \mathrm{A}$ & 12 \\
\hline 10 Oct 2009 & 1 & 1 & 0 & 10 \\
\hline 21 Apr 1927 & 2 & $\mathrm{~N} / \mathrm{A}$ & $\mathrm{N} / \mathrm{A}$ & 20 \\
\hline 26 Apr 1927 & 2 & 1 & 1 & 13 \\
\hline 26 Apr 1927 & 2 & 2 & 0 & 8 \\
\hline 13 Jul 1966 & 2 & 2 & 0 & 6 \\
\hline 9 Aug 1967 & 2 & 1 & 1 & 32 \\
\hline 18 Apr 1970 & 2 & 2 & 0 & 5 \\
\hline 14 Oct 1992 & 2 & $\mathrm{~N} / \mathrm{A}$ & $\mathrm{N} / \mathrm{A}$ & 14 \\
\hline 12 Aug 1990 & 2 & 1 & 1 & $\mathrm{~N} / \mathrm{A}$ \\
\hline 4 Feb 2008 & 2 & 1 & 1 & 15 \\
\hline 24 Apr 2008 & 2 & 1 & 1 & 26 \\
\hline 6 Jul 2009 & 2 & 0 & 2 & 3 \\
\hline 13 Jul 2008 & 2 & 1 & 1 & 7 \\
\hline 26 Oct 2008 & 2 & 1 & 1 & $L=12 ; R=10$ \\
\hline 22 Mar 1956 & 3 & 1 & 2 & 18 \\
\hline 21 Mar 2006 & 3 & 1 & 2 & 7 \\
\hline 15 Jul 2007 & 3 & 2 & 1 & 19 \\
\hline 23 Jul 2007 & 3 & 1 & 2 & 16 \\
\hline 5 Sept 2007 & 3 & 3 & 0 & 5 \\
\hline Unknown & 3 & $\mathrm{~N} / \mathrm{A}$ & $\mathrm{N} / \mathrm{A}$ & 25 \\
\hline 19 May 1965 & 4 & 3 & 1 & $\mathrm{~N} / \mathrm{A}$ \\
\hline 19 Aug 1967 & 4 & 2 & 2 & 2 \\
\hline
\end{tabular}

For each individual, the date of collection, total number of embryos $(\mathrm{N})$, and number of embryos on the left $(\mathrm{L})$ and right $(\mathrm{R})$ horns of the uterus are shown. Crown-rump length (CR) of embryos is measured in millimeters.

individuals that were highly mobile or dispersing. These data suggest that both males and females are establishing new territories or dispersing at similar rates. Animals that were captured over a 48-month period at a single building $(\mathrm{n}=56)$ ranged in mass from 20 to $80 \mathrm{~g}(\mathrm{mean}=46.7 \mathrm{~g})$. This range in mass suggests that there is considerable movement of all size classes and ages. This 1:1 sex ratio is consistent with other studies in the dry forests of Nicaragua (Genoways and Jones 1972) and western Mexico (Schnell et al. 2010).

The sex ratio for all age classes and countries also did not differ from 1:1, which is likely representative of wild populations. Although collection biases can affect these analyses, we believe these biases to be reduced because museum specimens were collected using a variety of techniques, including live traps, snap traps, incidental collection of dead animals, and collection with pistols.

We did not test sex ratios by age classes because of inherent difficulties in reliably assigning individuals to a class. Genoways and Jones (1972) classified individuals from western Nicaragua into five age classes based on tooth-wear patterns. They subsequently collapsed these into juvenile, subadult, and adult. Following their protocol and using their specimens, we attempted to classify the individuals from the Caribbean lowlands to these categories. However, we were surprised to find that tooth-wear patterns were quite different between the two regions; none of our individuals, including the heaviest and largest ( $>60 \mathrm{~g}$ ), could be classified older than wear category II, a young subadult. This difference in tooth-wear patterns suggests that the diets in these two regions are quite different. In the Caribbean lowlands, the dry season is characterized by somewhat less rain than in the rainy season, but seasonality is not as severe as in the dry forests of the Pacific lowlands. This contrast in seasonality undoubtedly causes a difference in the availability of food items. Therefore, tooth-wear patterns do not provide a reliable way to characterize individuals into age classes across the geographic range of vesper mice. Age classes also are difficult to assign on the basis of pelage. Juveniles show a grayer, softer coat; however, it is difficult to establish a standard coat color for subadults and adults that is consistent across the entire range or even within a single population. Future studies comparing Nyctomys sumichrasti populations should take special precautions when using morphological characters to classify age classes, as toothwear patterns and pelage are not the same. This may be true also for other species of tropical rodents.

\section{Reproduction}

Reproduction in Nyctomys sumichrasti occurs year-round throughout the range, including the Caribbean lowlands of Costa Rica (Table 1). These data are consistent with incidental captures in different habitats of pregnant or lactating females in different seasons (Fleming 1970, Genoways and Jones 1972, Sánchez-Hernández et al. 1999, Schnell et al. 2010). Although the Caribbean lowlands do not exhibit drastic seasonal changes between the rainy and dry seasons, many vertebrates, including several mammals, exhibit seasonal reproduction, which may be affected by food availability (Sasa et al. 2009, Stoner and Timm 2011). Vesper mice are seemingly not affected in the same way in terms of reproduction.

Testis size increases with body mass (Figure 1). Male reproduction was hard to assess on the basis of testis size because of the difficulty in determining the production of sperm without histological examination. In small mammals, testis size can adequately describe reproductive condition, and can be correlated with developmental stages, making it a reliable measure of male reproductive 
activity (Kenagy 1979). Although we are unable to produce a binary logistic regression curve for male reproductive activity similar to our analysis for females, it would be interesting in future studies to determine if the onset of sperm production is as variable as is reproduction in females, and how the onset of sperm production is correlated to testis size.

The binary logistic regression suggests that reproduction in females may begin at $20 \mathrm{~g}$; however, the probability of a female being reproductive does not reach $50 \%$ until 41 $\mathrm{g}$ and close to $100 \%$ until $60 \mathrm{~g}$ (Figure 2). Vesper mice in captivity grow quickly, reaching $40 \mathrm{~g}$ by week 3 and $55 \mathrm{~g}$ by week 11 (Birkenholz and Wirtz 1965). There is considerable overlap in mass among non-reproductive and reproductive females; the lightest reproductive female weighed $32.4 \mathrm{~g}$ and the heaviest non-reproductive female weighed $56.6 \mathrm{~g}$. This disparity in mass and reproductive state suggests that the start of reproduction may be highly variable among populations, individuals, and seasons. We present the binary logistic regression using mass instead of any other morphological character because mass is an easy and reliable measurement to take in the field and because body mass correlates to the probability of survival and reproduction of adult small mammals (Sauer and Slade 1985, 1987).

The fact that Nyctomys sumichrasti is tropical and arboreal may influence its reproductive strategies. Litter size for vesper mice is small (Table 2), which may be due to the ability of $N$. sumichrasti to reproduce year-round. Litter-size variation between species and geographic variation within species has been found to vary considerably in mammals, especially in rodents. Litter size for species found in the Neotropics varies from 1 in pacas [Cuniculus paca (Linnaeus, 1766)] to as many as 10-15 in cotton rats (Sigmodon). Hypotheses concerning litter size suggest that it should be greater, and the number of litters per year should be lower, in species that occur in geographic areas with shorter season length compared with more lowerlatitude or lower-elevation populations (Spencer and Steinhoff 1968). Studies for various rodent species have documented litter size to increase with latitude and elevation (Bowdre 1971, Long 1973, Birney et al. 1974, Oswald and McClure 1985). Vesper mice reproduce year-round and can produce consecutive litters quickly. In captivity, gestation is 30-38 days and one female gave birth to five litters during a 7-month period (Birkenholz and Wirtz 1965). In Costa Rica's Caribbean lowlands, we captured three females accompanied by offspring while being simultaneously pregnant. One female seemingly had two sets of litters with her as the pups weighed 8, 8.5, 24, and $29 \mathrm{~g}$, and she had three embryos measuring $5 \mathrm{~mm}$. The second female had three young weighing 18,19 , and $20 \mathrm{~g}$ while pregnant with three embryos measuring $19 \mathrm{~mm}$, while the third female had two young weighing 20.75 and $19 \mathrm{~g}$ and was pregnant also with three embryos measuring $16 \mathrm{~mm}$. Litter size for vesper mice is low, but they reproduce yearround, and likely in quick succession. These successive litters are interesting findings, given that few of our adult females were pregnant at the time of capture. Our data do not allow us to explore the reasons why some females reproduce in rapid succession whereas others do not - perhaps after a series of rapid reproductive bouts, there is a hiatus. In addition, these data suggest that vesper mice have postpartum or lactation estrus, resulting in the overlap of some litters (Gilbert 1984). Although we are unable to rigorously test for geographic and elevational variations in litter size for $N$. sumichrasti because of small sample sizes, our data suggest little to no variation geographically.

Vesper mice are highly arboreal, which could affect litter size. Their movement has been described as a "series of short, rapid dashes, even when not unduly excited" (Birkenholz and Wirtz 1965: 182). Small litter sizes may be advantageous given their need to be agile while moving on vines and trees. Members of this well-defined clade, the subfamily Tylomyinae - Nyctomys, Tylomys, Ototylomys, and Otonyctomys - and many other arboreal Neotropical rodents also have small litters ranging from one to four (Helm 1975, Reid 2009, Itzá-Ortiz et al. 2011). Unfortunately, little is known about the reproductive biology of the members of this clade, making it hard to compare litter size, seasonality of reproduction, and other life history traits that could provide insight into how reproductive strategies are similar for tropical, arboreal rodents.

\section{Embryo balance}

Mammals that have small litter sizes, have precocial young, and are reliant on fast, agile movements, for example, pronghorn [Antilocapra americana (Ord, 1815)] and plains viscacha [Lagostomus maximus (Desmarest, 1817)], often balance their embryos across uterine horns (Baird and Birney 1985, Birney and Baird 1985). Given that vesper mice have small litter sizes and are arboreal, we tested for embryo balance and found that this species did not balance embryos more than would be expected by chance. Several factors could influence these results. The majority of cricetid rodents (seven of nine) tested for embryo balance by Baird and Birney (1985) did not exhibit embryo balance, which may indicate a phylogenetic pattern; however, the species included in their analysis are not arboreal or saltatory. Our study was unable to reject the null hypothesis that embryos are randomly distributed 
between the left and right uterine horns; however, with only 15 pregnant females with two or more embryos and appropriate field notes, the power of the analysis was low. Dependence on fast, dexterous movement to escape predators, young with relatively high birth weights, and small litter sizes are characteristics hypothesized to be correlated with increased selection for balanced distribution of embryos. Many of these characteristics are shared by vesper mice and their close relatives, making this clade an interesting group with which to test this hypothesis, especially because our data suggest that this may not be the case for $N$. sumichrasti.

\section{Natural history}

Vesper mice are regularly found entering human homes in the Caribbean lowlands, as well as at mid and high elevations in the Monteverde region of Costa Rica. Homes that are susceptible to invasion are typically surrounded by vegetation. Most homes from which we received Nyctomys sumichrasti have adjacent gardens, or are surrounded by introduced plants or early-stage second growth. In homes, vesper mice make nests with papers, clothing, foam mattresses, and oven and refrigerator insulation. However, they rarely consume human food, and infrequently damage granola, seeds, or cheese stored in kitchens, whereas all other species of native mice that invade houses [Peromyscus nudipes (J.A. Allen, 1891), Reithrodontomys gracilis J.A. Allen and Chapman, 1897, and Tylomys watsoni Thomas, 1899], as well as introduced Rattus rattus (Linnaeus, 1758) and Mus musculus Linnaeus, 1758, damage stored grains and grain products. However, all rodents, including $N$. sumichrasti, are especially attracted

\section{References}

Arata, A.A. 1964. The anatomy and taxonomic significance of the male accessory reproductive glands of muroid rodents. Biol. Sci. Bull. Florida State Mus. 9: 1-42.

Baird, D.D. and E.C. Birney. 1985. Bilateral distribution of implantation sites in small mammals of 22 North American species. J. Reprod. Fertil. 75: 381-392.

Birkenholz, D.E. and W.O. Wirtz II. 1965. Laboratory observations on the vesper rat. J. Mammal. 46: 181-189.

Birney, E.C. and D.D. Baird. 1985. Why do some mammals polyovulate to produce a litter of two? Am. Nat. 126: 136-140.

Birney, E.C., J.B. Bowles, R.M. Timm and S.L. Williams. 1974. Mammalian distributional records in Yucatán and Quintana Roo, with comments on reproduction, structure, and status of peninsular populations. Occas. Pap. Bell Mus. Nat. Hist. Univ. Minnesota 13: 1-25. to chocolate. Vesper mice nibble novel objects, and one resident informed us that the mice frequently chewed on plastic soda caps and condoms. Homeowners report that vesper mice can be captured using peanut butter for bait.

On several occasions, females were seen moving with immatures clinging to the teats. Dead immatures, sometimes found by researchers along trails at La Selva, have likely fallen while clinging to an active female or from the nest. An immature individual that had hair but had not opened its eyes was found along a trail at La Selva where a coati (Nasua narica Linnaeus, 1766) was seen earlier rummaging through leaf matter on a tree branch, likely where there was a vesper mouse nest.

Acknowledgements: We thank Javier Guevara Sequeira and SINAC-MINAET who provided permits for research in Costa Rica. We are grateful to Deedra McClearn and the Organization for Tropical Studies for support of our research at La Selva, and Paul Foster at Reserva Ecológica Bijagual, Felix Corrales, Alex Gilman, and Richard LaVal for providing numerous specimens. Bernal Rodríguez (University of Costa Rica and MNCR) provided access to specimens deposited in those collections. Sue McLaren (CMNH), Bruce Patterson (FMNH), Ronald Pine (KU), Burton Lim and Mark Engstrom (ROM), and Neal Woodman (USNM) provided access to data from collections under their care. Special thanks to Guillermo Fandos Guzmán and Virginia Weigand-Noble for assistance, and to Helen Alexander, François Catzeflis, Richard LaVal, Brian O’Neill, Norman Slade, and an anonymous reviewer for helpful comments on the manuscript.

Received September 26, 2012; accepted January 30, 2013; previously published online March 5, 2013

Bowdre, L.P. 1971. Litter size in Sigmodon hispidus. Southwest. Nat. 16: 126-128.

Burt, W.H. 1960. Bacula of North American mammals. Misc. Publ. Mus. Zool. Univ. Michigan 113: 1-76.

Ceballos, G. 1990. Comparative natural history of small mammals from tropical forests in western Mexico. J. Mammal. 71: 263-266.

Corley, M.S., N. Ordonez-Garza, D.S. Rogers and R.D. Bradley. 2011. Molecular evidence for paraphyly in Nyctomys sumichrasti: support for a new genus of vesper mice? Occas. Pap. Mus. Texas Tech. Univ. 306: 1-10.

Dalquest, W.W. 1996. The Tehuantepec jungle. Midwestern State University Press, Wichita Falls, TX. pp. 63-70.

Domínguez-Castellanos, Y., L.F. Pimentel and G. Ceballos. 2007. Uso de hábitat de roedores arborícolas en la selva seca de la 
Reserva de la Biosfera Chamela-Cuixmala, Jalisco. Rev. Mex. Mastozool. 11: 21-40.

Fleming, T.H. 1970. Notes on the rodent faunas of two Panamanian forests. J. Mammal. 51: 473-490.

Fleming, T.H. 1973. The number of rodent species in two Costa Rican forests. J. Mammal. 54: 518-521.

Genoways, H.H. and J.K. Jones Jr. 1972. Variation and ecology in a local population of the vesper mouse (Nyctomys sumichrasti). Occas. Pap. Mus. Texas Tech. Univ. 3: 1-22.

Genoways, H.H., R.M. Timm and M.D. Engstrom. 2005. Natural history and karyology of the Yucatán vesper mouse, Otonyctomys hatti. In: (V. Sánchez-Cordero and R.A. Medellín, eds.) Contribuciones mastozoológicas en homenaje a Bernardo Villa. Instituto de Biología and Instituto de Ecología, UNAM, and Comisión Nacional para el Conocimiento y Uso de la Biodiversidad, México, D.F. pp. 215-220.

Gilbert, A.N. 1984. Postpartum and lactational estrus: a comparative analysis in Rodentia. J. Comp. Psychol. 98: 232-245.

Helm, J.D. III. 1975. Reproductive biology of Ototylomys (Cricetidae). J. Mammal. 56: 575-590.

Hooper, E.T. and G.G. Musser. 1964. The glans penis in Neotropical cricetines (family Muridae) with comments on classification of muroid rodents. Misc. Publ. Mus. Zool. Univ. Michigan 123: 1-57.

Hunt, J.L., J.E. Morris and T.L. Best. 2004. Nyctomys sumichrasti. Mammal. Species 754: 1-6.

Itzá-Ortiz, M.F., N.R. Van Wynsberghe, E.I. Sosa-Bibiano and F.J. Andrade-Narváez. 2011. Reproductive characteristics of a captive colony of big-eared climbing rats (Ototylomys phyllotis). Lab Anim. 40: 246-251.

Kenagy, G.J. 1979. Rapid technique for measurement of testis size in small mammals. J. Mammal. 60: 636-638.

Long, C.A. 1973. Reproduction in the white-footed mouse at the northern limits of its geographic range. Southwest. Nat. 18: 11-20.

McDade, L.A. and G.S. Hartshorn. 1994. La Selva Biological Station. In: (L.A. McDade, K.S. Bawa, H.A. Hespenheide and G.S. Hartshorn, eds.) La Selva: ecology and natural history of a Neotropical rain forest. University of Chicago, Chicago, IL. pp. 6-14.

Oswald, C. and P.A. McClure. 1985. Geographic variation in litter size in the cotton rat (Sigmodon hispidus): factors influencing ovulation rate. Biol. Reprod. 33: 411-417.

Peña, L.A., Y. Domínguez and B. Hernández. 2005. Nyctomys sumichrasti. In: (G. Ceballos and G. Oliva, eds.) Los mamíferos silvestres de México. Comisión Nacional para el Conocimiento y Uso de la Biodiversidad, México City. pp. 701-702.

Reid, F.A. 2009. A field guide to the mammals of Central America \& southeast Mexico, 2nd edition. Oxford University Press, New York. pp. 223-224.
Sánchez-Azofeifa, G.A., R.C. Harriss and D.L. Skole. 2001. Deforestation in Costa Rica: a quantitative analysis using remote sensing imagery. Biotropica 33: 378-384.

Sánchez-Hernández, C., M.L. Roméro-Almaraz, R.D. Owen, A. Núñez-Garduño and R. López-Wilchis. 1999. Noteworthy records of mammals from Michoacán, México. Southwest. Nat. 44: 231-235.

Sasa, M., D.K. Wasko and W.W. Lamar. 2009. Natural history of the terciopelo Bothrops asper (Serpentes: Viperidae) in Costa Rica. Toxicon 54: 904-922.

Sauer, J.R. and N.A. Slade. 1985. Mass-based demography of a hispid cotton rat (Sigmodon hispidus) population. J. Mammal. 66: 316-328.

Sauer, J.R. and N.A. Slade. 1987. Uinta ground squirrel demography: is body mass a better categorical variable than age? Ecology 68: 642-650.

Schnell, G.D., E.A. Gilland, C. Sánchez-Hernández, M.D.L. RomeroAlmaraz, M.L. Kennedy, T.L. Best and M.C. Wooten. 2010. Microhabitat preferences and spatial distribution of the vesper rat (Nyctomys sumichrasti) in Colima, Mexico. Mammal. Biol. 75: 482-495.

Sikes, R.S., W.L. Gannon, Animal Care and Use Committee of the American Society of Mammalogists. 2011. Guidelines of the American Society of Mammalogists for the use of wild mammals in research. J. Mammal. 92: 235-253.

Spencer, A.W. and H.W. Steinhoff. 1968. An explanation of geographic variation in litter size. J. Mammal. 49: 281-286.

Stoner, K.E. and R.M. Timm. 2011. Seasonally dry tropical forest mammals: adaptations and seasonal patterns. In: (R. Dirzo, H.S. Young, H.A. Mooney and G. Ceballos, eds.) Seasonally dry tropical forests: conservation and ecology. Island Press, Washington, DC. pp. 85-106.

Timm, R.M., 1994. The mammal fauna. In: (L.A. McDade, K.S. Bawa, H.A. Hespenheide and G.S. Hartshorn, eds.) La Selva: ecology and natural history of a Neotropical rain forest. University of Chicago Press, Chicago, IL. pp. 230-237.

Timm, R.M. and R.K. LaVal. 2000. Mammals. In: (N.M. Nadkarni and N.T. Wheelwright, eds.) Monteverde: ecology and conservation of a tropical cloud forest. Oxford University Press, New York. pp. 223-244.

Timm, R.M. and C. Vriesendorp. 2003. Observations on feeding behavior in the vesper mouse, Nyctomys sumichrasti. Mammal. Biol. 68: 126-128.

Timm, R.M., D.E. Wilson, B.L. Clauson, R.K. LaVal and C.S. Vaughan. 1989. Mammals of the La Selva-Braulio Carrillo complex, Costa Rica. North Am. Fauna 75: 1-162. 